\title{
DISTRIBUTION PATTERN OF GENUS TARAXACUM IN THE NEPALESE HIMALAYAS
}

\author{
Sanjeev Luintel ${ }^{1 *}$, Sabina Gyawali ${ }^{1}$, and Lokesh Ratna Shakya ${ }^{1}$ \\ ${ }^{1}$ Amrit Science College, Tribhuvan University, Lainchaur, Kathmandu, Nepal \\ *For correspondence: luintelsanjeev234@gmail.com
}

\begin{abstract}
The flowering plant diversity in Nepal is very rich with wide range of distribution due to overlap of different phytogeographical regions. In this study, we accounted the distribution pattern of genus Taraxacum belonging to the family Asteraceae. We included 14 species of Nepalese species which have wide range of altitudinal distribution i.e. from tropical region of Terai (720 m asl) to high Himalayas (4850 m asl) and east to west horizontal distribution with most of the species dominant in the central region of Nepal. Most of the species disappear or die during the dry winter season and their flowering starts by the starting of the Monsoon. These species within the genus have extended flowering period which is not strictly constrained by the monsoon. Taraxacum species richness increases along the elevation gradient from west to east across Nepal, in relation to the increased intensity of the monsoon.
\end{abstract}

Key words: Asteraceae, distribution,Nepalese Himalayas, Taraxacum

\section{INTRODUCTION}

The genus Taraxacum belongs to subtribe Crepidinae under tribe Cichorieae of sub family Cichoriodeae (APG-III, 2009; Xuejun et al., 2011). Mostly, the species are distributed in the arctic and temperate zones of the northern hemisphere with main diversity in mountains of Eurasia, a few species in temperate regions of the southern hemisphere (Xuejun et al., 2011; Daniela et al., 2009).

Despite being broad and general distributions patterns of Taraxacum species within Asia (Doorenbos et al., 1998; Uddin, 2007; Hughes, 2007), there have been no analytical studies based on geo-referenced specimen data. The Himalayas is an important area in terms of its position as the centre of several different floristic regions (Bhuju et al., 2007), and a detailed understanding of plant distributions within this region is key to understanding the biogeography of the Himalayan flora both locally and in a broader context. The aim of this paper is to describe Taraxacum species distribution patterns in the Nepalese Himalaya, and to interpret these patterns in relation to the climate and topography of the region.

\section{MATERIALS AND METHODS}

The study was undertaken as a part of revision of the genus Taraxacum for the Nepalese Himalayas. Specimens were collected from various localities in the Nepalese Himalaya during 2017-2018. This made it possible to study all taxa except T. amabile, T. elegans and T. monochlamydeum in their natural habitat, where habit, phenology and ecology were noted. For the preliminary identifications of the specimen, literature of Xuejun et al.(2011), Van Soest (1960,1963), Hooker J.D. (1882), Grierson et al.(2001) were consulted and further 
cross checked with the herbarium deposited at National Herbarium Centre (KATH) and Tribhuvan University Herbarium (TUCH). The plant specimens were also compared with the digital photographs of herbarium specimens of Royal Botanical Garden, Edinburgh (E), Bristish Museum (BM), Digital Images, Royal Botanical Garden, Kew (K), University Museum, University of Tokyo (TI), Natural Historical Museum, London (NHM) etc. The literatures available and the main protologue texts were consulted for the further identification and confirmation of the species. Distribution map of all the species were prepared by using package map and raster in R Studio (2018). Phenology data, expressed as number of flowering observations, was calculated from herbarium specimen data and field visit.



Figure 1 : Overall distribution of Taraxacum in Nepal (based on the herbarium records of species).

\section{RESULTS}

A total of 14 species were found in Nepal, 10\% of species (T. elegans and T. mitalii) from Eastern Nepal, $80 \%$ of species (T. eriopodum, T. lanigerum, T. paroulum, T.pseudostenoceras, T. sikkimense, $T$. staintonii, T. tibetanum) from Central Nepal and $10 \%$ species (T. amabile and T. nepalense) from Western Nepal.

Relying on the herbarium records, the taxa of Taraxacum are distributed from the East to West region of Nepal and more species are reported from Central and Western part of Nepal. Most of the species are distributed in the northern part of the country. Different colour and symbols have been used for different species (see fig 1). Taraxacum amabile (TA) was reported only from Western part of Nepal (Dhorpatan area-2900 m). Species T. elegans (TEl) were reported only from Eastern part from subalpine region (3300-3600 m). Taraxacum eriopodum (TEr) was reported from Eastern and Central part in the temperate to alpine region (2200$4340 \mathrm{~m}$ ). Taraxacum mitalii (TMi) was reported from Eastern and Central part from temperate to subalpine region $(2350-3450 \mathrm{~m})$. Taraxacum parvulum (TPa) was reported from all three parts of Nepal from tropical to alpine zone (720$4850 \mathrm{~m}$ ). Taraxacum nepalense (TN) was reported only from Western part of Nepal in temperate zone (Khaptad region 2980 m). Taraxacum sikkimense (TS) was reported from Central part of Nepal from temperate to sub alpine region (2280-3939 m). Taraxacum staintonii (TSt) was reported only in Central part from temperate to sub alpine region (2520-3710 m). Taraxacum tibetanum (TT) was reported in Central part from temperate to sub alpine region (2020-4000 m). Taraxacum mucronulatum (TM) was reported in Central region from sub alpine region $(1940 \mathrm{~m})$. Taraxacum pseudostenoceras (TPs) was reported in Central part from sub-tropical temperate region (1650-2874 m). Taraxacum lanigerum (TLa) was reported in Central part from alpine region (4380 m).

A number of the Taraxacum species in Nepal are known only from 1 or 2 localities (Shown in Fig. 1); hence they are very narrow Nepalese endemics; T. amabile, $T$. elegans, $T$. nepalense. Considering distributions at the regional level, there is a distinct gradient in species richness across the Nepalese Himalayas from Central to Western (Fig. 1).

Only 3 species (T. eriopodum, T. mitalii and $T$. paroulum) are abundant in the very seasonal and dryer and moist parts of Central, Western 
and few parts of Eastern Nepal. In Central Nepal, the regional species richness is higher due to both narrow endemics and species which have wider distributions to the west. Grierson (2001) described seven Taraxacum species from Bhutan, of which six species are present in Nepal. Hooker (1872-1879) has described one species of Taraxacum, i.e Taraxacum officinale.

Xuejun et al., (2011) has described 116 species (81 endemics, three introduced) in China and of Nepal where Taraxacum lies in tribe Cichorieae and six species Taraxacum I.e. T. eriopodum, T. lanigerum, T. mitalii, T. paroulum, T. sikkimense, T. tibetanum.

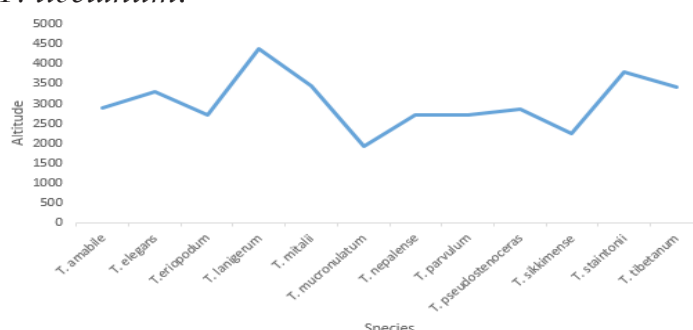

Figure 2: Number of Taraxacum species observed on different altitudinal ranges

Based on the herbarium specimens and literatures, vertical distribution of the genus ranges from Tropical to Alpine region (720 -4850 $\mathrm{m})$. The phenology of the genus in Nepal differs accordingly.

The flowering period starts from the month of January and terminates in the month of December, with the peak at the month of August during which all the species are in flowering and less in the month of December.

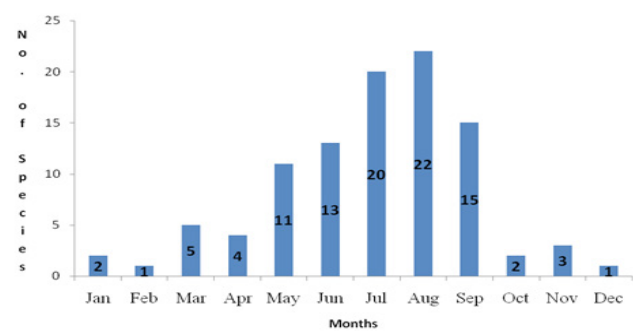

Figure 3: Number of species flowering at different months

\section{DISCUSSION}

The majority of Taraxacum species are light loving herbs, and hence the availability of water and how to cope with its seasonal absence are expected to be major determinants in shaping the distribution of the genus in areas with strongly monsoonal climates such as Nepal. Sustained monsoon rains commence in June, being preceded by a build-up of thundery rainstorms. The origin of the monsoon rains is the Bay of Bengal, and hence the intensity of the rains decreases and its altitudinal onset increases as one travels from east to west across Nepal (Lillesø et al., 2005). The Central to Western increase in Taraxacum species richness at the regional scale is correlated with this increased intensity of the monsoon in the Central and its onset at lower and warmer altitudes. The variation in rainfall and associated temperature mediation may account for the high species richness predicted to be in the Central region from modelled species distributions (Fig. 1). The differences observed between the modelled species richness and regional species richness patterns are due to two main factors. The species richness (Fig. 1) is based solely on specimen data and leaving many areas for which there are no collections, such as the Mid Central, under-recorded. The adaptation to seasonal habitats limits the distribution of Nepalese species in the Himalayan range to the west and east of Nepal and excludes them from areas with more unseasonal rainfall. In addition, earlier flowering means that many plants will have mature fruit achene by July and August, when the monsoon rains are still heavy. The results presented here show that the Taraxacum genus differs in their distributions, ecology and phenology. The importance of climatic factors such as the amount and seasonality of precipitation in shaping not only the flowering 
and fruiting periods of Nepalese plants but also their distribution and species richness. The Himalayan orogeny and development of the monsoon climate have undoubtedly influenced the evolution of Nepalese Taraxacum, and the genus will be an ideal model for phylogenetic investigations into the temporal and geographic origins of the Himalayan flora.

\section{ACKNOWLEDGEMENTS}

The authors thank the curators of KATH, TUCH for allowing the access to herbarium material.

\section{REFERENCES}

APG (Angiosperm Phylogeny Group) (2009). An update of the Angiosperm Phylogeny Group classification for the orders and families of flowering plants: APG III. Bot. J. Linn. Soc. 161: 105-121.

Bhuju U.R., P.R. Shakya, T.B. Basnet, and S. Shrestha (2007). Nepal Biodiversity Resource Book: Protected Areas, Ramsar Sites and World Heritage Sites. International Centre for Integrated Mountain Development (ICIMOD), Kathmandu, Nepal.

Daniela W., S. G. Christian, R. Carolin, F. Florence, R. M. Twyman., M. M. Bruno, F. Rainer, M. Jost, and P. Dirk (2009). Polyphenoloxidase Silencing Affects Latex Coagulation in Taraxacum Species. Plant Physiology. 151(1): 334-346.

Doorenbos, J., M.M. Sosef, and J.E de Wilde (1998). The Sections of Begonia, Including Descriptions, Key and Species Lists (Studies in Begoniaceae VI). (Wageningen Agricultural University Papers: Wageningen, The Netherlands). Backhuys Publishers, The Netherlands.

Grierson, A. C. and D. G. Long (2001). Flora of Bhutan. Royal Botanical Garden Edinburgh and Royal Government of Bhutan. 2(3): 1578-1584.
Hooker, J.D. (1882). The Flora of British India. Vol. III.401L. Reeve \& Co., London.

Hughes, M. (2007). An Annotated Checklist of Southeast Asian Begonia. Royal Botanic Garden Edinburgh, UK.

Lillesø, J.B., T.B. Shrestha, L.P. Dhakal, R.P. Nayaju and R. Shrestha (2005). The Map of Potential Vegetation of Nepal - a Forestry/ Agroecological/Biodiversity Classification System. Forest and Landscape Development and Environment Series 2-2005 and CFCTIS Document Series No.110. Forest and Landscape, Denmark.

Soest, J. L.Van (1960) New species of Taraxacum from Asia (includ. Rechingeri, Iter Iranicum II no. 40). Acta Bot. Need. 9: 302-326.

Soest, J. L. Van (1963). New species of Taraxacum from the Himalayan Region; Bull. British Mus. (Nat. Hist.) Botany. 2 10: 263-273.

Uddin, A. (2007). Distribution and status of Indian Begonia L. species. Journal of Economic and Taxonomy Botany 31(3): 591-597.

Xuejun, J, J. Kirschner, and J. Štěpánek, (2011). Taraxacum F.H. Wiggers. - In: Wu Z. Y., Raven P. H. \& Hong D. Y. (eds), Flora of China, p. 270-325, Missouri Botanical Garden Press and Science Press, Saint Louis and Beijing. 